\title{
TAXONOMY OF GENUS PSEUDOMONAS WITH SPECIAL REFERENCE TO THEIR MODES OF METABOLISM OF CARBON COMPOUNDS
}

\author{
HIROSHI IIZUKA and KAZUO KOMAGATA ${ }^{1}$ \\ Institute of Applied, Microbiology, University of Tokyo, Tokyo \\ Received October 23, 1962
}

Based on the results of extensive survey of cultural, biochemical, physiological and ecological characteristics of the species belonging to the genus Pseudomonas, the authors (1) have proposed a taxonomic division of the genus into three groups, i.e., fluorescent, achromogenic and chromogenic groups. Pseudomonas has been known to have the capacity of assimilating oxidatively various carbohydrates(2) as well as aromatic compounds such as phenol, benzoate, salicylate, $m$-hydroxy-benzoate, $p$-hydroxy-benzoate, etc. (3, 4). HAYNeS pointed out that the formation of 2-keto-gluconate from gluconate would be taken as a taxonomical characteristic of this genus, a suggestion that was cited in BERGEY's Manual of Determinative Bacteriology, 7 th ed. $1957(6)$. Considering the oxidative activities of Pseudomonas, Stanier $(\boldsymbol{y})$ discussed a taxonomical relation of this genus to Acetobacter. IKedA (8) proposed the name of "pseudo-oxidative bacteria" for the pseudomonads which oxidize glucose. Weak oxidative pseudomonads have been isolated by Seleen and STARK (9) from dairy products and by IzUKA and $\operatorname{Komagata}(10,11)$ from rice paddies, oil-brine and natural gas brine. That, however, the oxidative activity of pseudomonads can easily be modified by culture conditions has been reported by BENDER et al. (12), SteIN et al.(13), and LIU (14). This paper reports further taxonomical studies on the genus Pseudomonas with special reference to the metabolism of carbohydrates and other biochemically important carbon compounds viewed from the angle of classifying the genus in three groups mentioned above.

\section{MATERIALS AND METHODS}

Microorganisms. The pseudomonads listed in the previous paper were employed (1).

Cleavage of carbohydrates tested by liquid culture method. The organisms were cultured at $30^{\circ}$ for 2,4 , and 7 days, during which period observations were made up of the production of acid and gas, turbidity of the culture, etc. Two kinds of media were used, of which one

1) Present address: Central Research Laboratory, Ajinomoto Co., Inc., 2964, Suzuki-cho, Kawasaki, Japan. 
(peptone medium) was composed of $3.0 \mathrm{~g}$ peptone, $2.5 \mathrm{~g} \mathrm{NaCl}, 10.0 \mathrm{~g}$ carbohydrate, and $1,000 \mathrm{ml}$ distilled water, and the other (synthetic medium) was composed of $1.0 \mathrm{~g}\left(\mathrm{NH}_{4}\right)_{2} \mathrm{HPO}_{4}, 0.3 \mathrm{~g} \mathrm{KCl}, 0.2 \mathrm{~g} \mathrm{MgSO}_{4} \cdot 7 \mathrm{H}_{2} \mathrm{O}$, $10.0 \mathrm{~g}$ carbohydrate, and $1,000 \mathrm{ml}$ distilled water. Each medium was adjusted to $\mathrm{pH} 7.2$ and colored with bromcresol purple (B. C. P.). Durhum tubes were inserted into test tubes. Carbohydrates tested were glycerol, xylose, glucose, sucrose, lactose and starch.

Aerobic or anaerobic cleavage of carbohydrates tested by HUGH and LeIFson's method. Aerobic or anaerobic cleavage of carbohydrates was examined by Hugh and Leifson's method (15). The cells grown on nutrient agar slants were stabbed in semi-solid agar medium contaning carbohydrate, a part of the tubes were immediately sealed with sterilized liquid paraffin, while the rest of the tubes were left unsealed. The medium was composed of $2.0 \mathrm{~g}$ peptone, $5.0 \mathrm{~g} \mathrm{NaCl}, 0.3 \mathrm{~g} \mathrm{~K}_{2} \mathrm{HPO}_{4}, 3.0 \mathrm{~g}$ agar, $0.03 \mathrm{~g}$ B.C.P., $10.0 \mathrm{~g}$ carbohydrate (glucose or lactose), and $1,000 \mathrm{ml}$ distilled water and adjusted to $\mathrm{pH}$ 7.0. After 1 and 2 days' incubation at $30^{\circ}$, growth, turbidity, bubbling of gas and changing of color of B.C. P. were observed. As the medium was only poorly buffered, the production of acid could be sharply detected. According to the terminology used by HuGH and LeIFson, the occurrence of fermentative or anaerobic cleavage of carbohydrate was recognized when acid was produced in both sealed and unsealed tubes, and the occurrence of oxidative or aerobic cleavage of carbohydrate was concluded when acid production took place only in unsealed tubes.

Oxidation of gluconate. The method used was virtually the same as those reported by Haynes (5), and GABY and FreE (16). The bacterial cells cultured on nutrient agar slant for 18 to $24 \mathrm{hr}$ were suspended heavily in $2 \mathrm{ml}$ of $\mathrm{m} / 15$ phosphate buffer ( $\mathrm{pH} 7.2$ ) containing $2 \%$ of potassium gluconate, then incubated over-night at $30^{\circ}$. The reducing power was determined by the test with Fehling's solution.

Test of cytochrome oxidase. Test was made by the method reported by GABY and HadLeY (17). Bacteria was grown in nutrient broth (5 to $8 \mathrm{ml}$ each in volume) at $30^{\circ}$, and after 18 to $24 \mathrm{hr}$ of culture test was made by adding $0.2 \mathrm{ml}$ of $1 \%$ solution of $\alpha$-naphthol in ethanol and $0.3 \mathrm{ml}$ of $1 \%$ solution of $p$-aminodimethyl aniline oxalate in ethanol followed by vigrous shaking lasting for 1 to $3 \mathrm{~min}$. Appearance of blue color was regarded as the positive reaction of cytochrome oxidase.

Production of acetylmethyl carbinol. The production of acetylmethyl carbinol was tested by following the "Standard Methods for the Examination of Water and Sewage" of American Public Health Association (18). The medium was composed of $5.0 \mathrm{~g}$ glucose, $5.0 \mathrm{~g}$ peptone, $5.0 \mathrm{~g} \mathrm{~K}_{2} \mathrm{HPO}_{4}$, and $1,000 \mathrm{ml}$ of distilled water, and adjusted to $\mathrm{pH}$ 7.2. After 1, 3, and 5 days' incubation, $0.6 \mathrm{ml}$ of $5 \%$ solution of $\alpha$-naphthol in absolute ethanol and 0.2 $\mathrm{ml}$ of $40 \%$ aqueous solution of potassium hydroxide were added to $1 \mathrm{ml}$ of culture medium, and the mixture was left standing for 2 to $4 \mathrm{hr}$. The deve- 
lopment of ruby color was regarded as the sign of production of acetylmethyl carbinol. For the culture, use was also made of the medium reported by Sмгтн et al.(19), which gave the same results as the above mentioned medium as far as the formation of acetymethyl carbinol was concerned.

Utilization of carbon compouds. Utilization of carbon compounds was tested by measuring the turbidity of culture after 7 days of incubation. The medium used was composed of $1.0 \mathrm{~g} \quad \mathrm{NH}_{4} \mathrm{NO}_{3}, 1.0 \mathrm{~g} \mathrm{~K}_{2} \mathrm{HPO}_{4}, 0.5 \mathrm{~g}$ $\mathrm{MgSO}_{4}, 7 \mathrm{H}_{2} 0,1,000 \mathrm{ml}$ distilled water and the carbon compound to be tested. The amounts of the carbon compounds were: per $1 \mathrm{~L}$ of culture, $10.0 \mathrm{~g}$ in the case of carbohydrates and salt of organic acids; $2.0 \mathrm{~g}$; in the case of aromatic compounds; $0.5 \mathrm{~g}$ in the case of phenol. The medium was adjusted to $\mathrm{pH}$ 7.2. The substrates tested were glucose, gluconate, 2keto-gluconate, 5-keto-gluconate, citrate, succinate, ethanol, phenol, benzoate, salicylate, $m$-hydroxybenzoate, $p$-hyroxybenzoate, protocatechuate, gentisate, anthranilate and $p$-aminobenzoate.

\section{RESULTS}

Experimental results obtained are summarized in Tables 1, 2 and 3. Cleavage of carbohydrates tested by liquid culture method

Almost all the strains of the fluorescent group and some species of the chromogenic group produced acids from glucose in peptone media. In synthetic media several strains of the fluorescent group produced acids from glycerol, although they did not produce acids in peptone medium containing glycerol. Ps. chlororaphis produced acids from sucrose. Pseudomonads of the achromogenic group did not produce acids from any carbohydrates tested in peptone medium and in synthetic medium. Ps. stutzeri and Ps. rathonis grew well in the synthetic medium containing starch, but did not produce acids. The strains belonging to the chromogenic group showed different activities toward carbohydrates. Ps. perlurida and Ps. trifolii produced acids from lactose. All the strains of the three groups did not produce gas from carbohydrates.

Anaerobic cleavage of carbohydrates tested by Hugh and LeIFson's method

The anaerobic cleavage of carbohydrates was found only in two species: Ps. perlurida and Ps. trifolii which produced acids anaerobically from glucose and lactose (without producing gas). Hugh and Leifson's method was found to be more sensitive in detecting the acid production from carbohydrates than the liquid culture method described above. Nearly all the pseudomonads tested produced acid oxidatively from glucose. Even tested by this sensitive method, acid production from glucose could not be detected in the case of Ps. alcaligenes, Ps. desmolytica, Ps. dacunhae, and Ps. iners. 
Table 1. Cleavage of carbohydrates

\begin{tabular}{|c|c|c|c|c|c|}
\hline & \multicolumn{5}{|c|}{ Peptone medium } \\
\hline & $\begin{array}{l}\text { No. of } \\
\text { strain }\end{array}$ & Glycerol & Xylose & Glucose & Sucroce \\
\hline \multicolumn{6}{|l|}{ Fluorescent group } \\
\hline Ps. aeruginosa & 28 & - & V (8) & $\mathrm{V}(5)$ & - \\
\hline Ps. azotoformans & 20 & - & - & V (13) & - \\
\hline Ps. chlororaphis & 2 & - & - & - & - \\
\hline Ps. pavonacea & 6 & - & + & + & - \\
\hline Ps. schuylkilliensis & 21 & - & $\mathrm{V}(9)$ & V (14) & - \\
\hline Ps. aureofaciens & 1 & - & - & - & - \\
\hline Ps. cinnamona & 3 & - & + & + & + \\
\hline Ps. straminea & 1 & - & - & - & - \\
\hline Ps. nitroreducens & 6 & - & - & - & - \\
\hline Ps. ovalis & 27 & - & $\mathrm{V}(7)$ & V (19) & - \\
\hline Ps. rugosa & 3 & - & + & + & - \\
\hline Ps. fulva & 6 & - & - & $\mathrm{V}(2)$ & - \\
\hline \multicolumn{6}{|l|}{ Achromogenic group } \\
\hline Ps. putrefaciens & 4 & - & - & - & - \\
\hline Ps. alcaligenes & 5 & - & - & - & - \\
\hline Ps. stutzeri & 6 & - & - & - & - \\
\hline Ps. rathonis & 6 & - & - & - & - \\
\hline Ps. denitrificans & 4 & - & - & - & - \\
\hline Ps. desmolytica & 11 & - & - & - & - \\
\hline Ps. dacunhae & 3 & - & - & - & - \\
\hline Ps. riboflavina & 1 & - & - & - & - \\
\hline Ps. iners & 3 & - & - & - & - \\
\hline Ps. diminuta & 1 & - & - & - & - \\
\hline \multicolumn{6}{|l|}{ Chromogenic group } \\
\hline Ps. perlurida & 7 & - & + & + & + \\
\hline Ps. trifolii & 4 & - & + & + & + \\
\hline Ps. cerealis & 4 & - & - & - & - \\
\hline Ps. melanogenum & 4 & - & - & - & - \\
\hline Ps. lacunogenes & 13 & - & + & + & - \\
\hline Ps. ochracea & 2 & - & + & + & - \\
\hline
\end{tabular}

+ : Production of acid. - : No production of acid. V: Production of acid is variable from strain to strain. Figures in parentheses indicate the number of strains which produced acid. (+): Visible growth with production of acid. (-): Visible growth without production of acid. (V): Visible growth, and production of acid is variable from strain to strain. 0 : No growth. 
(Liquid Culture Method)

\begin{tabular}{|c|c|c|c|c|c|c|c|}
\hline \multirow[b]{2}{*}{ Lactose } & \multirow[b]{2}{*}{ Starch } & \multicolumn{6}{|c|}{ Synthetic medium } \\
\hline & & Glycerol & Xylose & Glucose & Sucrose & Lactose & Starch \\
\hline - & - & $(+)$ & $(\mathrm{V})(7)$ & $(+)$ & 0 & 0 & 0 \\
\hline - & - & $(+)$ & (V) (17) & $(+)$ & $(-)$ & 0 & 0 \\
\hline- & - & $(+)$ & $(-)$ & $(+)$ & $(+)$ & 0 & 0 \\
\hline- & - & $(+)$ & $(+)$ & $(+)$ & $(-)$ & $(-)$ & 0 \\
\hline- & - & $(+)$ & (V) (18) & $(+)$ & $(\mathrm{V})(7)$ & $(-)$ & 0 \\
\hline - & - & $(+)$ & 0 & $(+)$ & 0 & 0 & 0 \\
\hline- & - & $(+)$ & $(+)$ & $(+)$ & $(+)$ & $(-)$ & 0 \\
\hline - & - & $(-)$ & $(-)$ & $(+)$ & 0 & 0 & 0 \\
\hline- & - & $(+)$ & $(\mathrm{V})(3)$ & $(+)$ & (V) (2) & 0 & 0 \\
\hline- & - & $(\mathrm{V})(13)$ & (V) (9) & $(+)$ & $(-)$ & $(-)$ & 0 \\
\hline- & - & $(+)$ & $(\mathrm{V})(2)$ & $(+)$ & $(-)$ & 0 & 0 \\
\hline- & - & $(-)$ & $(-)$ & $(+)$ & $(-)$ & 0 & 0 \\
\hline- & - & 0 & 0 & 0 & 0 & 0 & 0 \\
\hline- & - & 0 & 0 & 0 & 0 & 0 & 0 \\
\hline- & - & $(-)$ & $(-)$ & $(-)$ & $(-)$ & $(-)$ & $(-)$ \\
\hline- & - & $(-)$ & $(-)$ & $(-)$ & $(-)$ & $(-)$ & $(-)$ \\
\hline- & - & 0 & $(-)$ & $(\mathrm{V})(3)$ & 0 & 0 & 0 \\
\hline- & - & 0 & 0 & 0 & 0 & 0 & 0 \\
\hline- & - & 0 & 0 & 0 & 0 & 0 & 0 \\
\hline- & - & 0 & 0 & 0 & 0 & 0 & 0 \\
\hline- & - & 0 & 0 & 0 & 0 & 0 & 0 \\
\hline- & - & 0 & 0 & 0 & 0 & 0 & 0 \\
\hline+ & - & $(+)$ & $(+)$ & $(+)$ & $(+)$ & $(+)$ & $(-)$ \\
\hline- & - & $(+)$ & $(+)$ & $(+)$ & $(+)$ & $(\mathrm{V})(3)$ & $(-)$ \\
\hline- & - & $(-)$ & 0 & 0 & 0 & 0 & 0 \\
\hline- & - & $(-)$ & $(\mathrm{V})(2)$ & $(\mathrm{V})(3)$ & (V) (2) & $(-)$ & $(-)$ \\
\hline- & - & $(+)$ & $(+)$ & $(+)$ & $(\mathrm{V})(1)$ & $(-)$ & 0 \\
\hline- & - & $(+)$ & $(+)$ & $(+)$ & $(-)$ & $(-)$ & 0 \\
\hline
\end{tabular}


Table 2. Biochemical

\begin{tabular}{|c|c|c|c|}
\hline & \multirow{3}{*}{ No. of strain } & \multicolumn{2}{|c|}{ Cleavage of carbohydrates tested } \\
\hline & & \multicolumn{2}{|c|}{ Glucose } \\
\hline & & Aer. & Anaer. \\
\hline \multicolumn{4}{|l|}{ Fluorescent group } \\
\hline Ps. aeruginosa & 28 & + & - \\
\hline Ps. azotoformans & 20 & + & - \\
\hline Ps. chlororaphis & 2 & + & - \\
\hline Ps. pavonacea & 6 & + & - \\
\hline Ps. schuylkilliensis & 21 & + & - \\
\hline Ps. aureofaciens & 1 & + & - \\
\hline Ps. cinnamona & 3 & + & - \\
\hline Ps. straminea & 1 & + & - \\
\hline Ps. nitroreducens & 6 & + & - \\
\hline Ps. ovalis & 27 & + & - \\
\hline Ps. rugosa & 3 & + & - \\
\hline Ps. fulva & 6 & + & - \\
\hline \multicolumn{4}{|l|}{ Achromogenic group } \\
\hline Ps. putrefaciens & 4 & + & - \\
\hline Ps. alcaligenes & 5 & - & - \\
\hline Ps. stutzeri & 6 & + & - \\
\hline Ps. rathonis & 6 & + & - \\
\hline Ps. denitrificans & 4 & + & - \\
\hline Ps. desmolytica & 11 & - & - \\
\hline Ps. dacunhae & 3 & - & - \\
\hline Ps. riboflavina & 1 & + & - \\
\hline Ps. iners & 3 & - & - \\
\hline Ps. diminuta & 1 & - & - \\
\hline \multicolumn{4}{|l|}{ Chromogenic group } \\
\hline Ps. perlurida & 7 & + & + \\
\hline Ps. trifolii & 4 & + & + \\
\hline Ps. cerealis & 4 & + & - \\
\hline Ps. melanogenum & 4 & + & - \\
\hline Ps. lacunogenes & 13 & + & - \\
\hline Ps. ochracea & 2 & + & - \\
\hline
\end{tabular}

Aer.: tubes were unsealed. Anaer.: tubes were sealed. 
characteristics

\begin{tabular}{|c|c|c|c|c|}
\hline \multicolumn{2}{|c|}{ by HUGH and LEIFSON's method } & \multirow{3}{*}{$\begin{array}{l}\text { Oxidation } \\
\text { of } \\
\text { gluconate }\end{array}$} & \multirow{3}{*}{$\begin{array}{l}\text { Acetylmethyl } \\
\text { carbinol }\end{array}$} & \multirow{3}{*}{$\begin{array}{l}\text { Cytochrome } \\
\text { oxidase }\end{array}$} \\
\hline \multicolumn{2}{|c|}{ Lactose } & & & \\
\hline Aer. & Anaer. & & & \\
\hline- & - & H & - & H \\
\hline- & - & + & - & H \\
\hline - & - & H & - & + \\
\hline- & - & H & - & + \\
\hline - & - & H & - & H \\
\hline - & - & H & - & H \\
\hline - & - & + & - & + \\
\hline - & - & H & - & + \\
\hline - & - & + & - & H \\
\hline - & - & H & - & + \\
\hline - & - & H & - & + \\
\hline- & - & + & - & + \\
\hline - & - & - & - & - \\
\hline- & - & - & - & - \\
\hline- & - & - & - & + \\
\hline- & - & - & - & H \\
\hline- & - & - & - & + \\
\hline- & - & - & - & + \\
\hline- & - & - & - & + \\
\hline- & - & - & - & - \\
\hline- & - & - & - & + \\
\hline- & - & - & - & $\perp$ \\
\hline+ & + & + & - & + \\
\hline+ & + & + & + & + \\
\hline- & - & - & - & + \\
\hline- & - & - & - & + \\
\hline- & - & H & - & + \\
\hline- & - & + & - & + \\
\hline
\end{tabular}


Table 3. Utilization of

\begin{tabular}{|c|c|c|c|c|c|c|c|}
\hline & 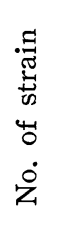 & 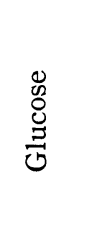 &  & 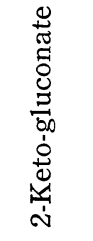 & 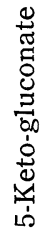 & 总 & 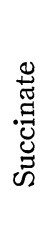 \\
\hline \multicolumn{8}{|l|}{ Fluorescent group } \\
\hline Ps. aeruginosa & 28 & + & + & + & - & + & + \\
\hline Ps. azotoformans & 20 & + & + & + & - & + & + \\
\hline Ps. chlororaphis & 2 & + & + & + & - & + & + \\
\hline Ps. pavonacea & 6 & + & + & + & - & + & + \\
\hline Ps. schuylkilliensis & 21 & + & + & + & - & + & + \\
\hline Ps. aureofaciens & 1 & + & + & + & + & + & + \\
\hline Ps. cinnamona & 3 & + & + & + & - & + & + \\
\hline Ps. straminea & 1 & + & + & - & - & + & + \\
\hline Ps. nitroreducens & 6 & + & + & + & - & + & + \\
\hline Ps. ovalis & 27 & + & + & + & - & + & + \\
\hline Ps. rugosa & 3 & + & + & + & - & + & + \\
\hline Ps. fulva & 6 & + & + & + & - & + & + \\
\hline \multicolumn{8}{|l|}{ Achromogenic group } \\
\hline Ps. putrefaciens & 4 & - & - & - & - & - & + \\
\hline Ps. alcaligenes & 5 & - & - & - & - & - & - \\
\hline Ps. stutzeri & 6 & - & - & - & - & + & + \\
\hline Ps. rathonis & 6 & - & - & - & - & + & + \\
\hline Ps. denitrificans & 4 & - & - & - & - & - & - \\
\hline Ps. desmolytica & 11 & $\mathrm{~V}(6)$ & + & - & - & + & + \\
\hline Ps. dacunhae & 3 & - & + & - & - & + & + \\
\hline Ps. riboflavina & 1 & - & - & - & - & - & - \\
\hline Ps. iners & 3 & - & - & - & - & - & - \\
\hline Ps. diminuta & 1 & - & - & - & - & - & - \\
\hline \multicolumn{8}{|l|}{ Chromogenic group } \\
\hline Ps. perlurida & 7 & + & + & + & - & + & + \\
\hline Ps. trifolii & 4 & - & + & + & - & + & + \\
\hline Ps. cerealis & 4 & + & $\mathrm{V}(1)$ & $\mathrm{V}(1)$ & - & + & + \\
\hline Ps. melanogenum & 4 & - & - & - & - & - & - \\
\hline Ps. lacunogenes & 13 & + & + & + & - & + & + \\
\hline Ps. ochracea & 2 & + & + & - & - & + & + \\
\hline
\end{tabular}

+ : Positive growth. - : No growth. V: Utilization is variable from strain 
various carbon compounds

\begin{tabular}{|c|c|c|c|c|c|c|c|c|c|}
\hline 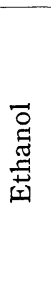 & $\begin{array}{l}\overrightarrow{0} \\
\text { d } \\
\text { 离 }\end{array}$ & 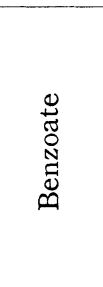 & 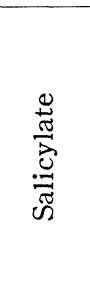 &  & 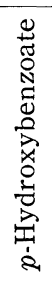 & 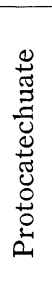 & 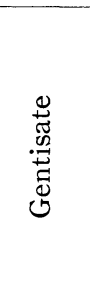 & 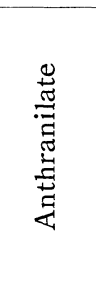 & 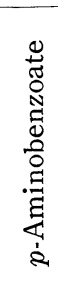 \\
\hline+ & - & + & - & - & + & + & + & + & - \\
\hline- & - & $\mathrm{V}(12)$ & - & - & + & + & $\mathrm{V}(1)$ & $\mathrm{V}(5)$ & - \\
\hline- & - & + & - & - & + & + & - & + & - \\
\hline+ & - & + & - & - & + & + & - & + & - \\
\hline+ & - & $\mathrm{V}(6)$ & - & - & + & + & $\mathrm{V}(1)$ & $\mathrm{V}(10)$ & - \\
\hline+ & - & + & + & - & + & + & - & + & - \\
\hline+ & - & $\mathrm{V}(2)$ & + & - & + & + & - & + & - \\
\hline+ & - & + & + & - & + & + & - & - & - \\
\hline+ & - & $\mathrm{V}(1)$ & - & - & + & + & $\mathrm{V}(1)$ & $\mathrm{V}(2)$ & - \\
\hline+ & $\mathrm{V}(8)$ & $\mathrm{V}(21)$ & $\mathrm{V}(3)$ & $\mathrm{V}(1)$ & + & + & $\mathrm{V}(2)$ & $\mathrm{V}(6)$ & - \\
\hline+ & - & + & - & - & + & + & - & + & - \\
\hline+ & - & - & - & - & + & + & - & - & - \\
\hline- & - & - & - & - & - & - & - & - & - \\
\hline- & - & - & - & - & - & - & - & - & - \\
\hline- & - & - & - & - & - & - & - & - & - \\
\hline- & - & - & - & - & - & - & - & - & - \\
\hline- & - & - & - & - & - & - & - & - & - \\
\hline+ & - & - & + & + & + & + & + & + & - \\
\hline- & - & - & + & + & + & + & + & + & - \\
\hline- & - & - & - & - & - & - & - & - & - \\
\hline- & - & - & - & - & - & - & - & - & - \\
\hline- & - & - & - & - & - & - & - & - & - \\
\hline- & - & - & - & - & - & + & - & - & - \\
\hline- & - & - & - & - & - & - & - & - & - \\
\hline- & - & - & - & - & - & - & - & - & - \\
\hline- & - & - & - & - & - & - & - & - & - \\
\hline+ & - & - & $\mathrm{V}(2)$ & - & + & + & - & + & - \\
\hline+ & - & + & + & - & + & + & - & - & - \\
\hline
\end{tabular}

to strain. Figures in parentheses indicate the number of strains which could grow. 


\section{Oxidation of gluconate}

A reducing substance, presumably 2-keto-gluconate, was abundantly produced from gluconate by the organisms belonging to the fluorescent group. The most powerful producers were Ps. aeruginosa, Ps. ovalis and Ps. schuylkilliensis. Less active producers were found in the chromogenic group, while there were no producers in the achromogenic group.

Test of cytochrome oxidase

Generally, the powerful activity of cytochrome oxidase was found in the members of the fluorescent group, especially in Ps. aeruginosa, Ps. azotoformans, Ps. schuylkilliensis, etc. The activity was lower in the organisms belonging to the achromogenic and chromogenic groups.

Production of acetylmethyl carbinol

The production of acetylmethyl carbinol was detected only in Ps. perlurida and Ps. trifolii.

\section{Utilization of carbon compounds}

The substances most generally utilized by the members of the pseudomonads are glucose, gluconate, and some other organic acids. In capacity of utilizing varieties of organic carbon compounds the members of the fluorescent group exceed, in general, by a great deal those belonging to the other groups. The poorest in this respect are the members of the achromogenic group, a few species such as Ps. desmolytica, Ps. dacunhae which can utilize, besides glucose, gluconate but not 2-keto-gluconate, $m$-hydroxybenzoate, $p$-hydroxybenzoate, etc. The aromatic compounds, especially $p$-hydroxybenzoate, are well utilized by the members of the fluorescent group, while they are utilized only by limited member of species belonging to the chromogenic group.

\section{DISCUSSION}

1. Metabolism of glucose and related organic acids

All the tested strains belonging to the fluorescent group were found to have the properties in common: of producing acid from glucose, of utilizing gluconate and 2-keto-gluconate, of accumulating a reducing substance, probalbly 2-keto-gluconate, in the presence of gluconate, and of showing a strong activity of cytochrome oxidase. The acids mainly produced by some strains (such as Ps. aeruginosa, Ps. ovalis, and Ps. schuylkilliensis) are gluconate and 2-keto-gluconate, while these acids are not produced by other strains belonging to the same group. Considering the results of penetrating studies made by Wood and Schwerd (20), and STern et al. (21) on the metabolism of carbohydrates by some pseudomonads, these findings may be taken as indicating that the initial steps of the oxidation of glucose by the fluorescent group is: glucose $\rightarrow$ gluconate $\rightarrow 2$-keto-gluconate. It may 
be remarked that the members of the fluorescent group never produced acetylmethyl carbinol from glucose.

The species belonging to the achromogenic group were found to be less "oxidative" than those of the fluorescent group. By the sensitive HugH and LeIfson's method, aerobic formation of slight amount of acid from glucose was detected in some strains, but no trace of acid formation could be ascertained for strains such as Ps. alcaligenes, Ps. desmolytica, Ps. iners, etc. grown on various carbohydrates. In general, the members of the achromogenic group are far less active and versatile in utilizing carbon compounds compared with those of the fluorescent group. Of this group a few species assimilated scuccinate, but no strain produced a reducing substance from gluconate.

Among the species of the chromogenic group, Ps. perlurida and Ps. trifolii are unique in metabolizing glucose and lactose anaerobically and in producing acetylmethyl carbinol. In this respect these species are similar to the bacteria belonging to Enterobacteriaceae, although the latter are different from the former in their character of forming gas from carbohydrates and peritrichous flagellation. On the other hand, Ps. lacunogenes of the chromogenic group produced a reducing substance, probably 2-ketogluconate, from gluconate. In respect to the mode of metabolism of carbon compounds, the chromogenic group seems to be composed of various different species.

2. Metabolism of aromatic compounds

Although a good deal of work has been done on the metabolism of aromatic compounds by various strains of Pseudomonas, its taxonomical significance has not yet been worked out. All the strains belonging to the fluorescent group utilized $p$-hydroxybenzoate, and protocatechuate. The utilization of benzoate, salicylate, gentisate, anthranilate, etc. vary with strain and species. Among the strains of the achromogenic group only two species, Ps. desmolytica and Ps. dacunhae, utilized $m$-hydroxybenzoate, $p$-hydroxybenzoate, protocatechuate, gentisate and anthranilate. One of the present authors, Komagata (22), who studied the oxidation of $m$-hydroxybenzoate by various strains of Pseudomonas, found that the oxidation is effected through different pathways in different strains. For example, $P$ s. ovalis belonging to the fluorescent group oxidized $m$-hydroxybenzoate via gentisate, while Ps. dacunhae of the achromogenic group split it through protocatechuate. In the chromogenic group, Ps. lacunogenes and Ps. ochracea utilized $p$-hydroxybenzoate, protocatechuate and some other aromatic compounds. It may be remarked that there was no strain in either of the three groups that could utilize $p$-aminobenzoate.

3. Characteristics of the three groups in respect to carbon metabolism

Based on the experimental results described above, the characteristics of the three groups of Pseudomonas in respect to carbon metabolism may be summarized as follows: 
i. Fluorescent group

Aerobic. Oxidative. Produce acid from glucose but not from lactose. Do not decompose carbohydrates anaerobically. Utilize glucose, gluconate, 2-keto-gluconate, citrate, and succinate. Utilize $p$-hydroxybenzoate, protocatechuate, and some other aromatic compounds, but not $p$-aminobenzoate. Produce a reducing substance(s), presumably 2-keto-gluconate, from gluconate. Acetylmethyl carbinol is not produced. Activity of cytochrome oxidase is relatively strong. Compared with the other two groups, this group is characterized in its markedly stronger activities: (i) of producing acids from carbohydrates, (ii) of producing a reducing substance, presumably 2-keto-gluconate from gluconate and (iii) of utilizing various organic carbon compounds, etc.

ii Achromogenic group

Aerobic. Production of acid from carbohydrate is feeble. Some species produce aerobically a slight amount of acid which is only detectable by Hugh and Leifson's method. A few species utilized glucose, gluconate, and related carbon compounds. Do not utilize 2-keto-gluconate. A few species utilize aromatic compounds. Do not produce a reducing substance from gluconate. Acetylmethyl carbinol is not produced. Activity of cytochrome oxidase is feeble. Oxidative activity is weak.

iii Chromogenic group

Aerobic. Produce acid from glucose. Ps. perlurida and Ps. trifolii produced acid anaerobically from glucose and lactose without producing gas. Utilization of carbon compounds varies with species. A few species produce a reducing substance(s), presumably 2-keto-gluconate, from gluconate. Ps. perlurida and Ps. trifolii produce acetylmethyl carbinol. Activity of cytochrome oxidase is feeble. Oxidative activity is moderate.

4. Pseudomonas as oxidative bacteria

According to Haynes (5), and Gaby and $\operatorname{Free}(16)$, the salient metabolic feature of Ps. aeruginosa is its oxidative activity, producing acids such as gluconate, 2-keto-gluconate from carbohydrate, etc. As we have seen, however, the pseudomonads possessing higher oxidative activity are limited only to the fluorescent group, especially Ps. aeruginosa, Ps. ovalis and Ps. schuylkilliensis. Oxidative activity or acid-producing activity is by no means the general characteristics of the genus Pseudomonas.

\section{SUMMARY}

Using 28 species and 202 strains belonging to the genus Pseudomonas, comparative studies were made of the capacity of utilizing various organic compounds, of metabolizing carbohydrate under aerobic and anaerobic conditions, of oxidizing gluconate, of producing acetylmethyl carbinol, etc. By and large, the metabolic features were found to be closely correlated to the pigmentation characteristics of the organisms, according to which the present authors have classified the genus Pseudomonas into three groups: 
namely fluorescent group, achromogenic group and chromogenic group. Nearly all the strains known as oxidative bacteria such as Ps. aeruginosa, Ps. ovalis, and Ps. schuylkilliensis were found to belong to the fluorescent group, while the strains belonging to the other two groups are generally poor in oxidative activities.

The authors wish to thank Mr. C. Sugiyama for his technical assistance.

\section{REFERENCES}

(1) H. Iizuka and K. Komagata: J. Gen. Appl. Microbiol., 9, 73 (1963)

(2) V. Pervozvanskit: Microbiol (USSR) 8149 (1939); cited from Chem. Abst. 34, $7321(1940)$

(3) R. Y. Stanier: J. Bacteriol., 54, 339 (1947)

(4) K. Arima, K. Komagata, S. Sugiyama and M. Kazama: J. Agri. Chem. Soc. Japan 23, 635 (1954)

(5) W. C. Haynes: J. Gen. Microbiol., 5, 939 (1951)

(6) R. S. BReEd et al.: Bergey's Manual of Determinative Bacteriology, 7 th ed. (1957) Williams and Wilkins

(7) R. Y. StanieR: J. Bacteriol., 54, 191 (1947)

(8) Y. IKedA: J. Agr. Chem. Soc. Japan 24, 51 (1950-1951)

(9) W. A. Seleen, C. N. Stark: J. Bacteriol., 46, 491 (1943)

(10) H. Irzuka: J. Gen. Appl. Microbiol., 3146 (1957), 4, 108 (1958)

(11) H. Iizuka and K. Komagata: Soil and Microbe (in Japanese) No. 2, 32 (1961)

(12) R. BENDER and M. Levine: J. Bacteriol., 44, 254 (1942)

(13) L. Stein, R. H. Weaver and M. Scherago: J. Bacteriol., 44, 387 (1942)

(14) P. LiU: J. Bacteriol., 64, 773 (1952)

(15) R. HUGH and Leifson: J. Bacteriol., 66, 24 (1953)

(16) W. L. GABY and E. Free: J. Bacteriol., 76, 442 (1958)

(17) W. L. GabY and C. Hadley: J. Bacteriol., 74, 356 (1957)

(18) American Public Health Association: Standard Methods for the Examination of Water and Sewage, 9 th ed., (1946); cited from M. J. Pelczar: Manual of Microbiological Methods (1957) McGraw-Hill

(19) N. R. Smith, R. E. Gordon and F. E. Clark: Aerobic Sporeforming Bacteria (1952) Agricultural Monograph No. 16 U. S.D. A.

(20) W. A. Wood and R. F. Schwerdt: J. Biol. Chem., 201, 501 (1953) [On the pathways of carbohydrate degradation in Pseudomonas, W. A. Wood reviewed in Bact. Rev. 19, 224 (1955)]

(21) I. J. Stern, C. H. WANG and C. M. Gilmour: J. Bacteriol., 79, 601 (1960)

(22) K. Arima, K. Komagata and S. Minoda: J. Agr. Chem. Soc. Japan, 23, 629 (1954) 